\title{
Forest Management in Madagascar: An Historical Overview
}

Daniela Raik

\begin{abstract}
Madagascar is regarded as one of the most important areas for biodiversity on Earth, and this biodiversity is found mainly in Madagascar's forests. Rural Malagasy people struggle to meet their daily food needs and often turn to the forest for new agricultural land. Efforts to curb deforestation and conserve threatened and endangered species undertaken by the Malagasy government and by international conservation and development organizations have been shaped by the history of forest management in the country. This paper traces the evolution of forest management in Madagascar from pre-colonial times to the present in an effort to contextualize current efforts to create new protected areas and transfer forest management responsibilities from the central government to local communities. In addition, the history of forest management is critically examined with respect to the assumptions about the role of government and the governed, as well as the dominant narrative that drove policy, providing context for understanding the approach currently underway in Madagascar.
\end{abstract}

\section{INTRODUCTION}

Madagascar is regarded as one of the most important areas for biodiversity on Earth. The island is a global priority for conservation (Goodman and Benstead 2003; Myers et al. 2000) because its biodiversity faces a wide variety of threats, including habitat loss and fragmentation, and overexploitation of commercially valuable species of plants and animals.

Changes in human activity on the island have resulted in an alarming rate of deforestation in Madagascar (Nelson and Horning 1993), putting both biodiversity and local livelihoods at risk (Donohoe 2003; UNDP et al. 2000). It is estimated that although deforestation rates have decreased from $0.82 \%$ per year between 1990 and 2005 to $0.55 \%$ per year between 2000 and 2005 (Conservation International et al. 2007), they remain high, resulting in negative impacts on biodiversity, hydrology, and carbon cycles. Global deforestation has been linked to a variety of direct and indirect factors, including the introduction of coffee cash cropping (Jarosz 1993), population growth (Green and Sussman 1990), timber export (UNDP et al. 2000), and local, national, and global political and economic factors (Kull 2000; Moser 2006). In addition to such global factors, major domestic threats to forests in Madagascar include clearing for subsistence agriculture (tavy), charcoal, timber, and mining (Ganzhorn

\author{
Human Dimensions Research Unit \\ Cornell University \\ Fernow Hall \\ Ithaca, NY 14850, USA \\ E-mail: dbr23@cornell.edu
}

et al. 1997). Although the practice of tavy may be a low-input, labor-efficient agricultural technique, it has negative impacts such as increased soil compaction and erosion (Erdmann 2003). However, other factors such as political resistance to restrictive policies have also been identified as contributing to current rates of deforestation (Klein 2002; Jarosz 1993).

Madagascar is also among the poorest countries in the world with per capita GDP at US $\$ 290$ in 2005, an infant mortality rate of $76 / 1000$ births, and only $45 \%$ primary school completion rate (The World Bank 2007). The country is stricken by frequent natural disasters such as cyclones, flooding, and drought. Food security is an issue as only $0.1 \%$ of the national surface area is under agricultural cultivation (estimate in 2000) because of poor soils, and people struggle to meet their daily food needs (The World Bank 2007). Thus, the pressure to eke out food production from the land leads to forest clearing.

Efforts to curb deforestation and conserve threatened and endangered species undertaken by the Malagasy government and by international conservation and development organizations have been shaped by the history of forest management in the country. This paper traces the evolution of forest management in Madagascar from pre-colonial times to the present in an effort to contextualize current efforts to create new protected areas and transfer forest management responsibilities from the central government to local communities. In addition, the history of forest management is critically examined with respect to the assumptions about the role of government and the governed, as well as the dominant narrative that drove policy, providing context for understanding the approach currently underway in Madagascar.

PRE-COLONIAL FOREST POLICIES AND PRACTICES Forest conservation and management in Madagascar has a long history that dates back to pre-colonial times (Table 1). James Sibree, a British missionary who spent 50 years on the island attributed deforestation to shifting agriculture and timber concessions: [Madagascar is] being diminished every year by the wholesale destruction of the forest in burning it for riceplanting, and it is grievous to see how recklessly it is cut down and destroyed for this and other more trivial reasons. The large concessions of forest land to European companies for timbercutting and plantations also tend in the same direction, and unless some plan of forest conservation is soon effected, the 
TABLE 1. Summary of the evolutions of forest policy in Madagascar

\begin{tabular}{|c|c|c|c|c|c|}
\hline PERIOD & & DOMINANT NARRATIVE & POLICY & ROLE OF GOVERNMENT & ROLE OF GOVERNED \\
\hline \multirow[t]{3}{*}{$\begin{array}{l}\text { Pre-Colonial } \\
\text { (through 1896) }\end{array}$} & & $\begin{array}{l}\text { Madagascar was once } \\
\text { fully forested }\end{array}$ & $\begin{array}{l}\text { Cutting live firewood } \\
\text { forbidden }\end{array}$ & $\begin{array}{l}\text { Create and enforce } \\
\text { repressive forest policy } \\
\text { (through banning } \\
\text { deforestation) }\end{array}$ & $\begin{array}{l}\text { Abide by centrally- } \\
\text { created laws }\end{array}$ \\
\hline & & $\begin{array}{l}\text { Deforestation resulted } \\
\text { from human activity }\end{array}$ & $\begin{array}{l}\text { Burning and settling in } \\
\text { forests forbidden }\end{array}$ & $\begin{array}{l}\text { Ensure forests (i.e., royal } \\
\text { property) are preserved } \\
\text { for the use of royals }\end{array}$ & \\
\hline & & & $\begin{array}{l}\text { Clearing the land for } \\
\text { agriculture forbidden }\end{array}$ & & \\
\hline \multirow[t]{4}{*}{$\begin{array}{l}\text { Colonial } \\
(1896-1961)\end{array}$} & & $\begin{array}{l}\text { Madagascar's forest } \\
\text { resources are for French } \\
\text { use and to enrich France }\end{array}$ & $\begin{array}{l}\text { Reforestation of fast } \\
\text { growing species }\end{array}$ & $\begin{array}{l}\text { Create and enforce } \\
\text { repressive forest policy } \\
\text { (through establishing } \\
\text { conservation areas or } \\
\text { banning deforestation) }\end{array}$ & $\begin{array}{l}\text { Abide by centrally- } \\
\text { created laws }\end{array}$ \\
\hline & & $\begin{array}{l}\text { Malagasy are unable to } \\
\text { manage forests }\end{array}$ & Hunting lemurs forbidden & $\begin{array}{l}\text { Manage forests uni- } \\
\text { laterally }\end{array}$ & $\begin{array}{l}\text { Resist centrally-created } \\
\text { laws by continuing } \\
\text { tavy as a cultural practice }\end{array}$ \\
\hline & & $\begin{array}{l}\text { Reforestation is needed } \\
\text { for human consumption } \\
\text { and development }\end{array}$ & $\begin{array}{l}\text { Forest fires and deforest- } \\
\text { ation forbidden }\end{array}$ & & \\
\hline & & & $\begin{array}{l}\text { Logging concessions } \\
\text { established }\end{array}$ & & \\
\hline \multirow[t]{8}{*}{$\begin{array}{l}\text { Post-Colonial } \\
\text { (1962-Present) }\end{array}$} & $\begin{array}{l}\text { Early Independence } \\
\text { (1962-1991) }\end{array}$ & $\begin{array}{l}\text { The State is the only legal } \\
\text { manager of forest } \\
\text { resources }\end{array}$ & Deforestation forbidden & $\begin{array}{l}\text { Create and enforce } \\
\text { repressive forest policy }\end{array}$ & $\begin{array}{l}\text { Abide by centrally- } \\
\text { created laws }\end{array}$ \\
\hline & & $\begin{array}{l}\text { Deforestation resulted } \\
\text { from human activity }\end{array}$ & $\begin{array}{l}\text { Hunting of several } \\
\text { species forbidden }\end{array}$ & $\begin{array}{l}\text { Manage forests uni- } \\
\text { laterally }\end{array}$ & $\begin{array}{l}\text { Resist centrally-created } \\
\text { laws by continuing tavy } \\
\text { and burning as cultural } \\
\text { practices }\end{array}$ \\
\hline & & & Reforestation mandatory & & \\
\hline & $\begin{array}{l}\text { NEAP Era } \\
\text { (1992-Present) }\end{array}$ & $\begin{array}{l}\text { Conservation is needed } \\
\text { to save Malagasy bio- } \\
\text { diversity }\end{array}$ & $\begin{array}{l}\text { Integrated conservation } \\
\text { and development } \\
\text { projects }\end{array}$ & Create protected areas & $\begin{array}{l}\text { Stop destructive forest } \\
\text { practices }\end{array}$ \\
\hline & & $\begin{array}{l}\text { Standardized models are } \\
\text { appropriate }\end{array}$ & Fences and fines & Enforce laws & $\begin{array}{l}\text { Use economic develop- } \\
\text { ment activities as an } \\
\text { alternative to resource } \\
\text { extraction }\end{array}$ \\
\hline & & & & $\begin{array}{l}\text { Provide economic } \\
\text { development opportun- } \\
\text { ities }\end{array}$ & \\
\hline & $\begin{array}{l}\text { Community-based } \\
\text { Forest Management }\end{array}$ & $\begin{array}{l}\text { Local people can manage } \\
\text { and conserve forests }\end{array}$ & $\begin{array}{l}\text { Decentralization of forest } \\
\text { management }\end{array}$ & $\begin{array}{l}\text { Transfer management } \\
\text { rights and responsibilities } \\
\text { to local people }\end{array}$ & $\begin{array}{l}\text { Conserve and manage } \\
\text { forests for long-term } \\
\text { sustainability }\end{array}$ \\
\hline & & $\begin{array}{l}\text { The state is ill-equipped } \\
\text { to manage forests effec- } \\
\text { tively everywhere }\end{array}$ & $\begin{array}{l}\text { Empowerment of local } \\
\text { forest users to make } \\
\text { decisions regarding } \\
\text { forests }\end{array}$ & $\begin{array}{l}\text { Monitor and oversee } \\
\text { local-level management } \\
\text { decisions }\end{array}$ & $\begin{array}{l}\text { Adhere to principles } \\
\text { established by the } \\
\text { government or third-party } \\
\text { NGOs }\end{array}$ \\
\hline
\end{tabular}

beautiful woods, with most of their flora and fauna, will eventually disappear (Sibree 1896:363).

Sibree's and others' observations regarding forest destruction reflect the attitudes of the time, which informed traditional forest conservation in Madagascar - top-down and repressive policy enforcement. Records dating as far back as the early nineteenth century document this approach to forest management. At that time, King Andrianampoinimerina (1745-1810) of Madagascar banned the cutting of live firewood and declared all forests in his kingdom as royal property. It is reported that he declared, "...it is forbidden for people to come to forge clandestinely arms in the forest because they can prepare a rebellion"
(Ratovoson 1979:22). Similarly, Prime Minister Rainilaiarivony declared that anyone caught cutting pristine forest would be chained in irons (Sibree 1881).

Two definitive pieces of legislation appeared in the mid-nineteenth century: The code of 101 Articles in 1868 and the code of 305 Articles in 1881 (Henkels 2001). Both concerned civil law, criminal law, and procedure (Ratovoson 1979). Article numbers 101-106 forbade burning of forests and settling of people in the forest. Article 105 forbade the practice of tavy: "One may not clear the forest by fire with the goal of cultivating rice fields, corn or other crops. One who clears by fire a new terrain or expands those which exist already, that person will be put in 
irons" (Ratovoson 1979 as translated by Henkels 2001-2002: 2). Early legislation such as this fueled the argument that Madagascar was once completely covered by forest and human activity alone had resulted in dramatic forest cover loss (Sibree 1896).

\section{COLONIAL FOREST PRACTICES}

Top-down approaches to forest management continued during the colonial period (1896-1961). Soon after the French took control in 1896 they established the Water and Forests Service and declared all forests to be under government control or in the public domain. The French also began an intense reforestation program on the central plateau and eastern escarpment of the island by establishing plantations of fast-growing, nonnative species such as eucalyptus and pine. They banned the killing of lemurs, and in 1927 established the first protected-areas system in the Africa region (Tyson 2000). In 1930, the French-led government passed Article 36, which prohibited all forest fires and other forms of deforestation (Montagne 2004). At this time, no distinction was made between forest fires started for the purposes of creating agricultural fields, and those associated with rejuvenating pasture land (Maldidier 2000). However, the French also contributed to deforestation in Madagascar. They planted much of the eastern lowlands with coffee, displacing many Malagasy farmers and clearing natural forest in the process (Tyson 2000). In fact, the beginning of massive deforestation is thought to be the direct result of coffee cash cropping (Jarosz 1993). Since local people no longer had access to lowlands, they began cultivating less fertile, higher slopes for slash-and-burn agriculture (tavy). French officials responded by prohibiting the clearing of forests for tavy.

The tavy ban backfired, leading to popular unrest and more deforestation. The Malagasy circumvented the prohibition where they could and resented the French for banning a practice that had been, and still is, a sustainable system in the tropics as long as population densities are low and fallow lengths are long, and representative of a means of subsistence inherited from the ancestors. The ban had the effect of elevating the tavy way of life to a ritual that symbolized resistance to colonial rule. As Jarosz (1993:374) notes, Resistance to the ban was more than pitting the right to subsistence over forest conservation; it embraced issues of power, labor control, and Malagasy identity. Not surprisingly, the French failed to eradicate the practice; likewise, the postcolonial state is beset with the same difficulties.

The French also directly contributed to deforestation in Madagascar by opening the state's forests to logging concessions. In their search for precious woods such as ebony, rosewood, and palissandre, concession owners clear-cut lands beyond the boundaries of their concessions. The Water and Forests Service was unable to enforce regulations due to a lack of labor, capital, and political will. Forest Service agents often allowed infractions to slip by because of their personal relationships with concession owners (Rapport du Service Forestier 1922).

The Colonial period is thus characterized by a palpable tension between the government and the governed. This tension focused on the practice of shifting cultivation as Colonists and local people struggled to advance their interests and impose their will on land use. Whereas for the Malagasy peasants, shifting cultivation was a cultural practice that affirmed their identity, linked them to the ancestors, and allowed them a means of resistance to state authority, the colonial authority saw shifting cultivation as a destructive practice that resulted in degraded grassland and hindered state-led forest extraction, labor control, and tax collection (Jarosz 1993).

\section{POST - COLONIAL FOREST POLICIES AND PRACTICES}

Madagascar gained its independence from France in 1961, but this had little effect on its forest management policy until very recently. In addition to the 1930 forest law that banned forest fires, other laws continued to be passed, including one that prohibited the hunting of several endangered species. In 1962, President Philibert Tsiranana declared that all men had to plant 100 seedlings a year or suffer a tax (Tyson 2000). This string of legislation reinforced the state as the only legitimate manager of forest resources in Madagascar, and contributed to a repressive relationship between the forest service and local people (Montagne 2004).

Nonetheless, despite decades of forest conservation laws, the decrease in Madagascar's forests throughout most of the twentieth century has been attributed to corruption among forest service employees, lack of motivation to adhere to forest policies among poor rural people, and the government's inability to monitor the forest and enforce policies because of a lack of resources, bad roads, and difficult terrain (Ganzhorn et al. 1997). Forest practices in Madagascar since 1930 can be characterized as open access, where individuals and groups exploiting forest resources were both uncontrolled and uncontrollable by the government. The result was a paradoxical conflict between illegal local-level forest exploitation regarded as legitimate by local people, and the legally-sanctioned forestry policies regarded as illegitimate by local people (Bertrand and Razafindrabe 1997; Montagne 2004). This pattern of behavior and interaction between the government and the governed continued through the 1960s and 1970 s.

\section{THE NEAP ERA}

In the mid-1980s, Madagascar's political climate began to change as it moved from an insular, quasi-communist political system closely tied to the Soviet Union, to a socialist democracy open to foreigners and foreign ideas. Due to this change, international biologists and ecologists began coming to Madagascar. Madagascar's reputation as a refuge for unique biodiversity was well known from its biogeography and from early Portuguese, British, and French records, but with modern methods and techniques, scientists were able to identify and classify many new organisms.

The move toward more open policy and increased interaction with foreigners also affected Madagascar's development agenda. The early 1990s met with a flurry of conservation and development activity. Bi-lateral and multi-lateral donor agencies such as the United States Agency for International Development (USAID) and the World Bank increased their involvement and funding levels. Policies and programs were developed, including Africa's first National Environmental Action Plan (NEAP). This plan was designed to include three five-year phases. Phase I (1992-1997) responded to the increasing consensus about the importance of Madagascar's unique biodiversity, and focused on the creation of protected areas and the institutional and organizational structures necessary 
for their management. This initial period was characterized by Integrated Conservation and Development Projects (ICDPS) in peripheral zones of protected areas, which were meant to compensate local people with micro-development projects as mitigation of restrictions on access to resources imposed by new protected areas.

Despite millions of dollars of investment, Phase I had mixed results (e.g., Barrett and Arcese 1995; Peters 1998). The policy of standardized projects made up of four main components (i.e., protected areas, buffer zones, compensation, and economic development), grew out of a deep-seated development discourse (Brechin et al. 2002). This discourse views development as a linear trajectory from less developed to developed, that should be followed by all nations regardless of culture, resource availability, or history. Similarly, the discourse advocates standardized approaches to achieving development from site to site (Scott 1998; Peet and Hartwick 1999) Results of this discourse and policy were that protected areas were disjointed from the economic development activities in peripheral zones meant to serve as alternatives to destructive environmental practices. Providing health centers or schools did not dissuade local people from practicing tavy, and the link between conservation and development was not made. Thus, the government, along with conservation and development donors and implementing organizations, imposed a model of development ill-suited to the local context in many ways, and local people struggled to navigate the new webs of relationships and institutions created by ICDPS.

Evaluations of Phase I activities indicated that the creation of a few dozen protected areas was not a viable approach to long-term sustainable management of Madagascar's natural resources (Montagne 2004). In addition, the ICDP model was deemed too centralized and standardized across sites to respond to local-level specificities. As a result, the Malagasy government and other actors interested in sustainable forest management began to look for new legal structures and institutional arrangements for forest governance. This trend reflects a global move toward more bottom-up, democratic, and participatory methods for designing and implementing natural resource-related policies and programs in developing countries (Durbin and Ralambo 1994; Peters 1998; Brechin et al. 1991; Chambers 1997).

\section{COMMUNITY-BASED FOREST MANAGEMENT}

In the 1990s, faced with high rates of deforestation and inefficient forestry practices, the Malagasy government, with support from international conservation and development organizations, pushed for a new community-based natural resources management policy (Bertrand 1994; Rajaonson et al. 1995; Kull 2002). This policy, known as GELOSE, is applicable to forests, pastures, wildlife, and water. It aims to promote better resource management through local-level management, rule-setting, and enforcement, leading to better environment stewardship. GELOSE was signed into law on September 10, 1996 (law No. 96-025), and in 1997, the law was incorporated into the new national forestry policy (Law 97-107 and Decree 97-1200).

The GELOSE law allows for the creation of tripartite negotiated contracts among the state (represented by the forest service), the municipality (i.e., mayor's office), and a voluntary association of community residents created for the purpose of this contract (i.e., Communauté de Base or COBA). The law does not stipulate how this association should be constituted - it may be constituted through some form of representation or include all village residents. However, no local resident can be excluded from the COBA association. Under GELOSE contracts, communities regulate resource use through dina, a locally-developed social agreement whose form pre-dates state-sanctioned rules (Henkels 2001; Marcus 2000). Contract negotiations are coordinated by an "environmental mediator" and the process for establishing a GELOSE contract, which is described in legislation, includes 22 steps (Kull 2002).

Only in 2000 did the GELOSE law receive the first two installments of its decrees (décrets d'application). Because implementation of GELOSE was viewed as complex and cumbersome, a piece of enabling legislation specific for forests was defined under order No. 2001-122. This policy, Contractual Forest Management (Gestion Contractualisée des Forêts or GCF), simplifies the process for transferring forest management rights to communities by eliminating the need for an environmental mediator and reducing the contract signatories to two: the state (represented by the regional office of the Ministry of Environment, Water, and Forests), and the COBA (Kull 2002; Antona et al. 2004).

The move toward community-based natural resources management gained momentum during the second of three five-year phases of the NEAP. Phase II (1998-2003) activities emphasized a landscape approach to natural resources management outside protected areas and included participatory approaches to conservation and development (Montagne 2004). GELOSE and GCF contracts were a major component of Phase II activities, and currently over 400 GELOSE and GCF contracts exist throughout Madagascar.

Law 96-025 allowed for local populations to take part in decision making and actions related to local natural resource management, but it did not specify the institutional mechanisms by which this should occur (i.e., representation by election, volunteer membership, etc.). GELOSE and GCF were mainly an experiment to transfer the management of local forest resources for subsistence use as well as conservation (Randrianasolo 2000); a small number of contracts attempted to generate economic benefits via the harvest of forest products, including timber. Subsistence use in this case included harvesting of timber products for domestic consumption such as home construction and firewood.

Phase III of the NEAP (2004-2008) aims to mainstream the environmental agenda and also includes a major initiative to expand the protected area network. In 2003, the President of Madagascar, Marc Ravalomanana, declared his "Durban Vision" to expand the surface area of protected areas from 1.7 million hectares to 6 million hectares by 2012. This will put Madagascar within IUCN's recommended standard of having $10 \%$ of the country's land area under some form of protection. The protected area network, which will include both pre-existing and new protected areas, is now known as the System of Protected Areas of Madagascar (Système des Aires Protegées de Madagascar, or SAPM). Under SAPM, the majority of new protected areas are likely to be co-managed, and one vision for this co-management is that local communities will partner with government through COBA structures set up via GELOSE and GCF contracts. 
GELOSE and GCF arrangements, whether or not associated with protected areas, can have a strong conservation component. Despite rhetoric of local empowerment to make decisions about forest management, these governance arrangements are substantially controlled. COBA are given management responsibilities for an initial period of three years, renewable for ten years. They are not granted land tenure (though under GELOSE there is an option for enhanced tenure security). In addition, third parties such as conservation and development NGOs play a strong role in orienting management plans and zoning of these areas. Their field agents often initiate community-level discussions regarding resource management and their agendas are often reflected in the management plans or zoning systems developed for community-managed areas (e.g., Antona et al. 2004). Thus, the effort to decentralize forest management in Madagascar has transferred some powers to local people while maintaining a certain level of centralized control.

\section{CONCLUSION}

Forest management in Madagascar has evolved over the last century from top-down, centralized legislation that aimed to restrict access to forest resources to more decentralized governance forms that attempt to put local people at the center of decision making. Although by tracing legislation this trend is clearly apparent, implementing truly decentralized governance is a complex process that involves institutional structure and power dynamics that are difficult to modify. In Madagascar, decentralized governance arrangements are changing the web of interactions among actors such as government, international agencies, and local communities in an attempt to shape power dynamics. Nevertheless, it is still unclear the extents to which local communities are able to capture the opportunity these changes represent and ensure their interests are represented. understanding how these dynamics are evolving is a crucial step for monitoring the implementation of these policies and improving upon them over time. Additional research is needed to assess how these institutional changes are affecting principles of good governance such as participation, accountability, and transparency in decision making.

\section{ACKNOWLEDGEMENTS}

Funding for this work was provided by the National Science Foundation Graduate Research Fellowship, the Mario Einaudi Center for International Studies International Research Travel Grant, and the Cornell University Center for the Environment Student Environmental Research Grant. We are grateful to residents of the communities, forest agency staff, and NGO personnel who participated in this study.

\section{REFERENCES}

Antona, M., Bienabe, E. M., Salles, J., Pechard, G., Aubert, S., and Ratsimbarison, R. 2004. Rights transfers in Madagascar biodiversity policies: achievements and significance. Environment and Development Economics 9: 825-847.

Bertrand, A. 1994. Revue documentaire prealable a l'elaboration d'une politique et d'une strategie de gestion des feux de vegetation a Madagascar. CIRAD November.

Bertrand, A., and Razafindrabe, M. 1997. Lever l'insécurité foncière: une des premières clefs du développement de Madagascar. Paper read at Colloque International Politiques des Structures et Action Foncière, 24-26 November, at La Réunion.
Brechin, S. R., West, P. C., Harmon, D., and Kutay, K. 1991. Resident peoples and protected areas: a framework for inquiry. In: Resident peoples and national parks: social dilemmas and strategies in international conservation, P. C. West and S. R. Brechin (eds.), pp 5-28. University of Arizona, Tuscon.

Brechin, S. R., Wilshusen, P. R., Fortwangler, C. L. and West, P. C. 2002. Beyond the square wheel: Toward a more comprehensive understanding of biodiversity conservation as social and political process. Society \& Natural Resources 15, 1: 41-64.

Chambers, R. 1997. Whose Reality Counts? Putting the First Last. Intermediate Technology, London.

Conservation International, IRG, Ministere de I'Environnement des Eaux et Forets, and USAID. 2007. Change in Natural Forest Cover Madagascar 1990-2000-2005. Conservation International, Washington, DC.

Donohoe, M. 2003. Causes and health consequences of environmental degradation and social injustice. Social Science \& Medicine 56, 2003: 573-587.

Dufils, J. M. 2003. Remaining forest cover. In: The Natural History of Madagascar, S. M. Goodman and J. P. Benstead (eds.), pp 88-96. University of Chicago, Chicago.

Durbin, J. C., and Ralambo, J. A. 1994. The role of local people in the successful maintenance of protected areas in Madagascar. Environmental Conservation 21, 2: 115-120.

Erdmann, T. K. 2003. The dilemma of reducing shifting cultivation. In: The Natural History of Madagascar, S. M. Goodman and J. P. Benstead (eds.), pp 134-139. University of Chicago Press, Chicago.

Ganzhorn, J. U., Langrand, O., Wright, P. C., O'Connor, S., Rakotosamimanana, B., Feistner, A. T. C. and Rumpler, Y. 1997. The state of lemur conservation in Madagascar. Primate Conservation 17: 70-86.

Goodman, S. M., and Benstead, J. P. (eds.). 2003. The Natural History of Madagascar. University of Chicago, Chicago.

Green, G. M., and Sussman, R. W. 1990. Deforestation history of the eastern rain forests of Madagascar from satellite images. Science 248, 4952: 212-215.

Henkels, D. 2001. A close up of Malagasy environmental law. Vermont Journal of Environmental Law 3: 1-16.

Jarosz, L. 1993. Defining and explaining tropical deforestation: Shifting cultivation and population growth in colonial Madagascar (1896-1940). Economic Geography 69, 4: 366-379.

Klein, J. 2002. Deforestation in the Madagascar Highlands - Established ,truth' and scientific uncertainty. GeoJournal 56: 191-199.

Kull, C. A. 2000. Deforestation, erosion, and fire: Degradation myths in the environmental history of Madagascar. Environment and History 6: 423-450.

Kull, C.A. 2002. Empowering pyromaniacs in Madagascar: Ideology and legitimacy in community-based natural resource management. Development and Change 33, 1: 57-78.

Maldidier, C. 2000. Note de lecture des quatre rapports d'évaluation externe dU PAE. ONE - SCAC, Antananarivo.

Marcus, R. R. 2000. Cultivating Democracy on Fragile Grounds: Environmental Institutions and Non-Elite Perceptions of Demogracy in Madagascar and Uganda. Unpubl. Ph.D. thesis, University of Florida.

Montagne, P. 2004. Analyse rétrospective du transfert de gestion à Madagascar et aperçu comparatif des axes méthodologiques des tranfserts de gestion sous loi 96-025 et sous décret 2001-122. Consortium RESOLVE - PCP - IRD, Antananarivo.

Moser, C. M. 2006. A selection correction for cloud cover in satellite images in an analysis of deforestation in Madagascar. In: Working Paper: University of Western Michigan.

Myers, N., Mittermeier, R. A., Mittermeier, C. G., Da Fonseca, G. A. B. and Kent, J. 2000. Biodiversity hotspots for conservation priorities. Nature 403: 853-858.

Nelson, R., and Horning, N. 1993. AVHRR-LAC estimates of forest area in Madagascar, 1990. International Journal of Remote Sensing 14: 14631475.

Peet, R., and Hartwick, E. 1999. Theories of Development. The Guilford Press, New York.

Peters, J. 1998. Transforming the integrated conservation and development project (ICDP) approach: Observations from the Ranomafana National 
Park Project, Madagascar. Journal of Agricultural and Environmental Ethics 11: 17-47.

Rajaonson, B., Randriamarolaza, L. P., Randrianaivo, D., Ratsimbazafy, E., Rejo Tsiresy, V. and Bertrand, A. 1995. Elaboration d'une politique et d'une strategie de gestion des feux de vegetation a Madagascar. Office National de l'Environnement, Antananarivo.

Randrianasolo, J. 2000. Capitalisation des Experiences en Gestions Contractualisées de Forets à Madagascar: Fichiers d'Experiences. Intercooperation Suisse, Antananarivo.

Ratovoson, C. 1979. Les problèmes du tavy sur la côte est Malagache. Madagascar Review de Géographie 35, 148.

Scott, J. C. 1998. Seeing Like a State: How Certain Schemes to Improve the Human Condition Have Failed. Yale University, New Haven.

Sibree, J. 1881. The Antananarivo Annual and Madagascar Magazine. London Missionary Society Press, Antananarivo.
Sibree, J. 1896. Madagascar Before the Conquest: The Island, the Country, and the People. T. Fisher Unwin, London.

The World Bank. 2007. Madagascar Data Profile. The World Bank 2007 [cited January 4 2007]. Available from http://devdata.worldbank.org/external/ CPProfile.asp?CCODE+MDG\&PTYPE $=$ CP.

Tyson, P. 2000. Island of dreams. In: The Eighth Continent: Life, Death, and Discovery in the Lost World of Madagascar. HarperCollins, New York.

UNDP, UNEP, World Bank, and World Resources Institute. 2000. World Resources 2000-2001: People and Ecosystems: The Fraying Web of Life. In: World Resources Series. United Nations, Washington, DC. 